\title{
Pioneer Des Moines Postoffices
}

\author{
By IsAac BrandT ${ }^{\circ}$
}

Terms of Postmasters Began

Josiah Smart, December 13, 1845

Dr. Thos. K. Brooks, March 2, 1846

Phineas M. Casady, December 31, 1846

Robert L. Tidrick, October 26, 1848

Hoyt Sherman, June 26, 1849

Wesley Redhead, February 11, 1853

John Teasdale, May 6, 1861

George C. Tichenor, April 18, 1867

James S. (Ret) Clarkson, July 28, 1871

John Beckwith, March 4, 1879

William H. Merritt, August 13, 1886

Isaac Brandt, June 3, 1890

Ed. H. Hunter, July 26, 1894

Dr. Lewis Schooler, September 18, 1898

John McKay, Sr., December 10, 1902

Joseph I. Myerly, March 19, 1907

Louis C. Kurtz, June 1, 1911

George A. Huffman, July 1, 1915

Zene C. Thornburg, July 1, 1924

Edwin J. Frisk, May 4, 1925

Lemuel S. Hill, February 1, 1934

Edith M. Johnson, December 1, 1940

First located at Fort Barracks

The first postal service in Des Moines was purely pioneer. The first letters that came to the soldiers were brought up on boats that carried supplies and provisions to the officers in the barracks, and an occa-

-Isaac Brandt was a Des Moines citizen long prominent in political and civic activities, who served as postmaster from 1890 to 1894, about the last public service of a long public career. He also had served as deputy state treasurer $1867-73$, as state representative in the Fifteenth General Assembly from Polk county 1873-4; a member of the city council and mayor pro tem in 1877; appointed by President Arthur one of three commissioners to inspect one of two divisions of the Northern Pacific railroad in 1883; a personal friend of John Brown who often stopped at the Brandt home in Des Moines, which was one of the stations of the "underground railroad"; solicited, collected and paid into treasury of the Iowa State Fair society more than $\$ 50,000$ in providing grounds for the permanent location of the state fair at the state capital; active in the Iowa Pioneer Lawmakers association and served as its president. 
sional letter to the men at Ewing \& Phelps' trading post. Our early or pioneer postoffices and the first newspapers published in Des Moines always will be a matter of public interest.

The first postoffice was established in December, 1845 , and was named "Raccoon River." On December 13, 1845, Josiah Smart was appointed postmaster. He was a half-breed, the interpreter of Indian Agent Major Beach, and had an Indian squaw for his wife. He was a very successful man in conveying the wishes of the Indians to the white people. Mail was brought on horseback in a pair of government saddle bags, securely locked. It made the Indians smile when they saw that lock placed on leather. The mail was light. When letters came for persons that Mr. Smart did not know, they were placed under a bolt of red flannel in the back part of the store room of the trading post.

The store house or trading post was on the east side of the Des Moines river, near the lot where the stone packing house now stands. Mr. Smart's term of office only lasted seventy-eight days, from December 13, 1845, to March 2, 1846, at which time Dr. Thos. K. Brooks was appointed postmaster. The office still retained the euphonius name of "Raccoon River."

Dr. Brooks removed the office to his residence, a two-story log house in the edge of the timber, up on the hill. The doctor was not very proud of the office, yet he said someone must take it that had a house. He was a very cheerful man, and could laugh at a joke on himself as well as anybody else. Mails came once a week, and the doctor always stayed at home on that day.

One morning, the first week in October, he had a very urgent call to go and see a sick Indian a few miles out of town. He said he would be glad to go, but this was mail day and he expected a large mail. "I cannot go today, but I will come and see your man in the morning." The good old squaw took his refusal to go 
to heart very much, and said, "Poor Indian dies." The postmaster said: "Die or no die, I must attend to Uncle Sam's mail." The squaw lingered around, and before she left the mail came. The doctor unlocked the saddle bags, thrust in his hands, but found no mail. He then shook the saddle bags vigorously, but nary a letter came out. He was very much surprised, and turned to the squaw, and, with one of his pleasant smiles, said: "I will be up to see your man in the morning." True to his promise, he saddled his horse and made good time to the Indian camp. When he arrived the squaw went out to meet him with a queer gleam in her eye. She said, with a smile, "Nan, man. He's gone hunting." The doctor saw the point well and returned to his postoffice as much pleased as if he had saved the Indian's life.

The place where Dr. Brooks' hewed log house stood is now lot 8, on East Court avenue in I. N. Thomas' subdivision of block 18, in Brooks \& Co.'s addition. Before his term of office expired, when R. W. Snyder became connected with the trading post, he took the office back to the agency storeroom. In June, 1846, the town of Ft. Des Moines was surveyed and the name of the Raccoon River postoffice was changed to Fort Des Moines.

On Dec. 31, 1846, P. M. Casady was appointed postmaster. For a short time he kept the postoffice at the trading post. Believing that the mail should be kept in a more secure place, he removed it to one of the buildings in the soldiers' barracks, known as 'Coon Row, on the banks of the Raccoon river, near the foot of Second street. He made a decided improvement. He had a book stand that he had made in Keosauqua. $\mathrm{He}$ fitted it up with pigeon holes for the letters and put a pen and inkstand where the public could use it, and insisted that people should write letters and let the world know where Fort Des Moines was located.

A Postman Carried the MaIL

There were no newspapers published in Fort Des 
Moines at that time. Mail came regularly once a week. It was still carried on horseback, and one of the postmen, Isaac Warfull, is still living in Des Moines, and very much enjoys telling the thrilling adventures he encountered with blind roads, high waters, snakes, wolves and Indians on his route between here and Fairfield. He never failed to deliver the mail on time to Postmaster Casady. Mr. Casady was very careful of the letters. If he had to go around town on business, he would put the letters in his hat, and if he met a man to whom the letter was addressed he would give it to him, provided he had the 25 cents to pay the postage. Therefore, P. M. Casady was not only one of the first postmasters, but was the very first letter carrier in Des Moines.

In the summer of $1847, \mathrm{Mr}$. Casady had urgent business that would cause him to be away from home for some time; therefore he appointed J. M. Wallace as his deputy. When he returned home he found that Wallace had removed the bookcase, inkstand, etc., into another building in the soldiers' barracks, where there were whiskey and all kinds of strong drink kept for sale. The postmaster asked him why he had made the change. He replied with the most innocent and honest look upon his countenance: "I thought it would be no harm to take it where all people had to come." The postmaster thought differently and had his bookcase and inkstand taken back to their proper place.

In the spring of 1848 , he removed the postoffice to a small frame building on Second street, between Market and Vine streets. The mail was then brought from Fairfield, the distributing office for western Iowa, by the way of Oskaloosa to Des Moines.

In August, 1848, Mr. Casady was elected state senator from Polk county and all western Iowa. Hoyt Sherman, then a young man not quite 21 years of age, was his deputy. It was thought best to have a new postmaster, but as Sherman was not 21 years old, Robert L. Tidrick, an active, energetic young lawyer, was ap- 
pointed postmaster on Oct. 26, 1848. Mr. Tidrick qualified with the understanding that Hoyt Sherman would act as deputy. Mr. Tidrick did not care to be putting in his time looking after letters for other people when he could do so much better attending to his own business. Hoyt Sherman attended to the postoffice very satisfactorily, and, becoming 21 years of age on Nov. 1, 1848 , he was eligible to become postmaster. On June 26,1849 , he was appointed, and immediately became more interested in the growth of Des Moines.

\section{A Newspaperman Appears}

Among the new arrivals was a young lawyer from New York, who wore store clothes and a plug hat. He was nicknamed the "little city fellow." (The word "dude" was unknown then.) After looking the town over, he concluded it was large enough to support a newspaper. Accordingly, in June, 1849, the Iowa Star made its appearance in the firmament of Des Moines. It was a spicy, well-gotten-up paper, full of good sense, wisdom and wit. Everybody was proud of it. It was naturally Democratic, but the Whigs subscribed for it quite willingly. Some of them wanted to pay for it in crabapples. This the proprietor objected to and said he did not deal in that kind of fruit. He said his name was Barlow Granger, but he would not take Barlow knives or crabapples for the Iowa Star. A compromise was agreed upon, and he took trust for pay, which meant business in pioneer days.

The Iowa Star was taken by everybody and sent to their friends in the East. The young postmaster, Hoyt Sherman, was a clerk in his brother James Sherman's store, but whenever he had time he would go fishing. He always knew whom he had letters for. If a man came along that had a letter in the postoffice he would set down his pole and scamper over to the office and hand it to him. In one of his contemplative moods he concluded to put up a building for a postoffice. Accordingly, in June, 1850, he erected Fort Des Moines postoffice building. It was first class for the times. It was 
a $16 \times 16$ one story frame, all of native lumber and had a lock on the door. It was regarded as a first class improvement, and he received many compliments for his energy and enterprise. It was located on Second street on the lot where Green \& Son's foundry now stands. Postage had been reduced to 10 cents, which induced more people to write letters.

\section{New MaIl Line From Davenport}

During the summer of 1850 , a mail line was opened up from Davenport to Iowa City, and from there to Oskaloosa, and from there to Fort Des Moines, which increased the postoffice receipts very much; also a line to Council Bluffs. The census taken in June, 1850, gave Fort Des Moines a population of 502; males, 290, females 212.

Also, during the summer of 1850, Lampson P. Sherman, brother of the postmaster, established the Fort Des Moines Gazette. In politics it favored the Whig party. Fort Des Moines was now on the highway to success-two well-established papers that in every issue sounded the advantages of the town at the Raccoon Fork. The Iowa Star was the nucleus from which the Des Moines Leader came, and Fort Des Moines Gazette the parent organ of The lowa State Register. The postmaster worked vigorously for both papers, but was supposed to favor the Gazette.

On February 10, 1853, Wesley Redhead was appointed postmaster. He kept the office in the Sherman building a short time and then moved it across the street to his own little shop and book store, where he kept it until November, 1856, when he removed it away up town, to Sherman's brick block, on the corner of Third and Court avenue. The dedication of that new building "away up town" was an immense affair. Every window in the entire structure had dozens of brilliant old tallow dips shedding dazzling rays of light out over the great throng. In this new office $\mathrm{Mr}$. Redhead placed a large bookstore, which added much to the business interests of Des Moines. 
John Teasdale was appointed postmaster May 6, 1861. He kept the postoffice in the same room with Mr. Redhead's bookstore until January 1, 1866, at which time he moved the postoffice into a new frame building erected for that purpose by Mr. Hoyt Sherman, in the rear of the Sherman block on Third street.

George C. Tichenor was appointed postmaster on April 17, 1867. He kept the office in the same building until the latter part of the year 1870, when he moved into the new government building.

James S. (Ret) Clarkson was appointed postmaster July 27, 1871; John Beckwith on March 3, 1879; Wm. H. Merritt on August 12, 1886; Isaac Brandt on June 2, 1890; Edward H. Hunter on July 26, 1894; and Lewis Schooler on September 17, 1898.

The postal service receipts had grown from a very small sum in 1845 , to January 1,1898 , to paying the government net about $\$ 145,000$ per year. The two newspapers that were established in 1849 and 1850 have grown even faster than the postal service. If I should state the hundreds of pounds of papers they send out daily all over the United States, it would astonish the natives. The two grand, good men that founded these papers "builded greater than they knew." I feel happy to say that they are both living and well and are very proud of the prosperity of Des Moines.

Des Moines, Iowa, 1898.

\section{First Bible Printed in U. S.}

A unique Bible phonetically rendered in the Algonquin language of the Massachusetts Bay Colony Indians has been acquired by the library at Columbia University. Printed in the early 1660 s for missionary purposes it is thought to be the first Bible ever published in the area that now comprises the United States, and a very rare specimen. 
Copyright of Annals of Iowa is the property of State of Iowa, by \& through the State Historical Society of Iowa and its content may not be copied or emailed to multiple sites or posted to a listserv without the copyright holder's express written permission. However, users may print, download, or email articles for individual use. 